\title{
5 Sustainable development and climate change adaptation: goal interlinkages and the case of SIDS
}

\author{
Michelle Scobie
}

\begin{abstract}
The international climate and sustainable development agendas are of particular significance for Small Island Developing States (SIDS), which are especially vulnerable to climate change impacts. SIDS' government departments are small in size with very limited financial, administrative, and technical resources. Policymakers must manage multiple national and international sustainable development and climate change forums, commitments, and policies. This chapter therefore asks: what framework can be used to integrate and simplify international sustainable development and climate policies? How can SIDS' national policies be integrated into such a framework? And what are the areas where fragmented or disconnected policies exist and (how) can policy fragmentation be reduced? The chapter thus makes three novel contributions to the literature. First, it proposes the use of interlinkages as a tool or framework to integrate climate and sustainable development goals. Second, it tests this approach with St. Lucia's national policy as a case study, finding commonalities but also identifying important differences between international and national goals. Third, it provides empirical evidence of the multiplicity and complexity of climate and sustainable development goals and targets that policymakers of SIDS must attempt to implement. This linkages framework and empirical example can help government agencies and development partners that work with SIDS on sustainable development and/or climate change to more efficiently use limited resources through integrated policy interventions.
\end{abstract}

Cite this article: Scobie, M. (2019): Sustainable development and climate change adaptation: goal interlinkages and the case of SIDS. In: Klöck, C. \& Fink, M. (eds.): Dealing with climate change on small islands: towards effective and sustainable adaptation? (pp. 101-122). Göttingen: Göttingen University Press. https://doi.org/10.17875/gup2019-1213 


\section{Introduction}

Small Island Developing States (SIDS) are located in the Pacific, Indian, Mediterranean, and Caribbean Oceans. They share many development challenges. These include small size, remoteness, narrow resource and export base, lack of economies of scale for export industries, economies highly exposed to global markets, heavy dependency on imports, food and energy insecurity, extremely high levels of national debt, high levels of poverty and inequality, and climate change impacts including more frequent and intense natural hazards (CARICOM, 2013). SIDS must manage sustainable development and climate change adaptation and mitigation agendas with limited financial, administrative, and technical resources. Government departments traditionally implement these policies in separate agencies but joint policy development and execution could bring savings to the public purse (Scobie, 2016).

This study examines the problem of thematic and action areas of complexity and fragmentation between the United Nations' 2015 sustainable development goals (SDGs) in general and those related specifically to climate change (SDG13) in relation to SIDS. It offers a helpful framework to locate areas of conceptual and practical convergence between international, regional, and national climate change and sustainable development policies.

SIDS' national sustainable development and climate change policies are formed in part by several international agendas. Beyond the 2015 United Nations SDGs (17 goals and 169 targets) and the 2015 Paris Agreement of the United Nations Framework Convention on Climate Change (UNFCCC), SIDS as a group have had their own sustainable development agendas. Barbados hosted the first UN Global Conference on SIDS' Sustainable Development in 1994 where SIDS developed the Barbados Programme of Action (BPOA) - the first SIDS sustainable development roadmap that outlined several development policy areas of special concern for SIDS: limited resources, climate change impacts and sea-level rise, coastal and marine resources, energy resources, freshwater resources, human resource development, management of wastes, capacity building for national institutions and administrations, natural and environmental disasters, regional institution building and technical cooperation, science and technology, tourism, transport, communication, and biodiversity. Since the Barbados Conference, the SIDS' sustainable development agenda has been developed in subsequent UN SIDS conferences. The most recent UN SIDS summit, held in Apia, Samoa in 2014 produced an outcome document, the SIDS Accelerated Modalities of Action (SAMOA) Pathway, that highlighted 17 sustainable development thematic and implementation goals and areas, ranging from climate change and disaster risk reduction (DRR) to gender equality and sustainable transportation.

SIDS in the BPOA also identified what they considered as pathways or actions for implementing sustainable development goals: capacity building; cooperation in the transfer of environmentally sound technologies; finance; institutional develop- 
ment at the national, regional, and international levels; trade; and economic diversification. SIDS also highlighted the need for partnerships and improved monitoring and accountability (UNGA, 2014).

In addition to this broad level of cooperation across diverse regions, SIDS have region-specific goals and implementation agendas. In 2013, CARICOM, the regional economic integration and functional cooperation organization for fifteen Caribbean SIDS, produced the Kingston Outcome Document - a region-specific preparatory document for the 2014 Samoa summit (CARICOM, 2013). CARICOM also has a 2015-2019 Strategic Plan that addresses areas and action items related to sustainable development and climate change. Perhaps recognising the problem of having a plethora of goals and targets, and in an attempt to rationalise the implementation of multiple priorities, the CARICOM Strategic Plan sought to target, "a narrow range of specified outcomes within specified timeframes, focusing on a few practical and achievable goals" (CARICOM, 2014, p. i). However, even these lists of policy priorities are daunting especially in the context of SIDS' capacity constraints.

Using St. Lucia as a test case, this chapter illustrates where international and regional policy areas intersect with national ones. St. Lucia is an Eastern Caribbean state with a population of about 183,000. Like many Caribbean Islands, St. Lucia suffered a worsening fiscal balance during the 2007/2008 financial crisis. The average fiscal balance for $2004-2013$ was $-4.9 \%$ of GDP. It has a high public debt and a large fiscal deficit. For example, its debt to GDP ratio exceeded the internationally accepted 60\% debt sustainability benchmark in 2013. Unemployment is high among youth, who account for over $56 \%$ of its population (Government of St. Lucia, 2015a). St. Lucia depended heavily on the export of bananas, and since 2006 that industry has not recovered from the loss of preferential treatment for its bananas in the United Kingdom market after the United States' banana company Chiquita successfully challenged that preferential regime at the World Trade Organisation (Ferguson, 1998; Moberg, 2005).

St. Lucia experiences climate change through increased frequency and intensity of extreme climatic events: higher amounts of rainfall, flooding, extensive landslides, strong winds, drought, rising sea levels and temperatures, damage to infrastructure and housing, loss of life and livelihoods, and increased vector borne diseases including dengue, chikungunya, and zika. The 2009/2010 drought (Taylor, Jones, \& Stephenson, 2016) was not an anomaly and the country will face future water deficits that are already a concern for tourism establishments, small farmers, and food security (Government of St. Lucia, 2015a, p. viii). Annual storms and hurricanes affect the private sector, which suffers losses caused by logistical interruptions, resource constrains, and so on (Government of St. Lucia, 2015a). In October 2010, Hurricane Tomas caused damages in excess of US\$ 350 million, or “43.4 percent of Saint Lucia's GDP - nine times its agricultural GDP, three times its tourism GDP, 62 percent of exports of goods and services, 19 percent of its gross domestic investment and 47 percent of its public external debt" (Govern- 
ment of St. Lucia, 2015a, p. viii). St. Lucia will have to adapt to these extreme events and other climate change impacts and climate adaptation policy is integral to the state's development policy.

Climate change mitigation is also part of St. Lucia's climate and development policy. At the time of this study, St. Lucia's climate change and sustainable development goals were contained in the St. Lucia 2015 Intended Nationally Determined Contribution (INDC) (of November 17, 2015) and the 2015 Saint Lucia Climate Change Adaptation Policy (Adaptation Policy). Although the island contributes approximately $0.0015 \%$ to global emissions (per capita rate of 3.88 tCO2eq) (Government of St. Lucia, 2015b), it has ambitious climate goals and is committed to lead by example to reduce global emissions (St. Lucia Renewable Energy Roadmap, 2016). Mitigation policies will have important economic co-benefits for St. Lucia's economy: clean energy alternatives can reduce its fuel import bill since it is heavily dependent on fossil fuels. To date, however, its climate goals have been difficult to achieve and renewable energy deployment uptake is slow. Renewables are still very costly and the regulatory framework needed to give potential investors security of integration of sustainable energy into the existing power grid is still to be implemented (Scobie, 2019). The expected investment cost (capital finance) of the mitigation targets for 2030 are US\$ 218 million and the government costs (planning, research, policy making, implementing regulations, enforcement, capacity building, public education) are estimated at US $\$ 23$ million (Government of St. Lucia, 2015a, p. vii).

How do SIDS' policymakers, faced with limited resources and acute economic and environmental vulnerabilities, integrate multiple goals and targets into national policy in a coherent and efficient manner to facilitate policy integration and efficient policy implementation? This chapter addresses this research question in three stages. First, it develops a framework to simplify, integrate, and link the SDGs with SDG13 on climate change. Second, it determines how far international climate and sustainable development policies, as exemplified by the SDGs, accord with national policy for SIDS. Third, it finds the goals and policy areas now framed as standalone action points that facilitate and entrench fragmented or disconnected goals.

Recent studies have sought to find pathways to link policy areas. Some have highlighted linkages between water- and the health-related SDGs (Hall, Ranganathan, \& Raj, 2017) or SDG14 for oceans (in particular to avoid overfishing) and the other SDGs (Singh et al., 2018). This paper continues this line of research and makes three novel contributions. First, it identifies the linkages between the SDGs in general and the climate goal specifically and proposes this model of associating the two policy realms as a way to facilitate policy integration. Second, it offers the framework as a lens to relate the international goals to regional and national policy agendas for climate and sustainable development with St. Lucia as a case study. Third, the study provides empirical evidence of the overwhelming multiplicity and complexity of climate and sustainable development goals and targets that policymakers from SIDS must integrate and makes the case for better integration of 
sustainable development and climate targets in international and national development policy and projects.

\section{Interlinkages approach to SDGs and climate change}

Finding synergies is important for good governance. The environmental governance literature has sought to understand the synergies, interlinkages, or interconnections between actors, actor interests, and contexts (Ruiz-Mallén, FernándezLlamazares, \& Reyes-García, 2017), goals (Griggs et al., 2014; Måns Nilsson, Griggs, Visbeck, Ringler, \& McCollum, 2017; M. Nilsson, Lucas, \& Yoshida, 2013), agendas (Roberts, Andrei, Huq, \& Flint, 2015), and policy domains or approaches (Boas, Biermann, \& Kanie, 2016a; Reed, Van Vianen, Deakin, Barlow, \& Sunderland, 2016). Interlinkages, interconnections, synergies, and so on refer to the relationships between factors, their overlap, similarity, and causational elements. Studies that try to highlight the interlinkages or areas of commonality between policy areas are useful to identify, for example, possible compatibility (Ribas, Lucena, \& Schaeffer, 2017), or co-benefits (von Stechow et al., 2016), or to avoid unwanted impacts from actions in one sector or by one group of actors. Several studies have set the foundation for this chapter through the analysis of specific SDGs from thematic and implementation perspectives. Thematic studies have explored commonalities between related goals (Griggs et al., 2014; Måns Nilsson et al., 2017), examining how particular goals relate to or are integrated with each other (Le Blanc, 2015), such as water, food, and energy (Ringler et al., 2016; Yillia, 2016); nutrition and agriculture (Shingirai \& Happy, 2017); water and health (Hutton \& Chase, 2016); health and development (Janardhan, 2016); and women's empowerment and education (Zhang, Prouty, Zimmerman, \& Mihelcic, 2016). Others point to the apparent dissonance and trade-offs between development goals and climate change mitigation in specific areas such as energy security (Wagner, Ross, Foster, \& Hankamer, 2016), sustainable energy (von Stechow et al., 2016), poverty alleviation (Nelson, Lemos, Eakin, \& Lo, 2016), dependence on fossil fuels and carbon neutrality and economic growth (Schandl et al., 2016), and climate and development policy (Reed et al., 2016; von Stechow et al., 2016).

Some studies have focused on implications for implementing the SDG goals: climate adaptation and development policy in developing states (Lamb, 2016; Sherman et al., 2016); the SDGs' transformative power for economic, climate, and social justice policy (Koehler, 2016); and the reduced effectiveness of SDGs implementation processes because of insufficient focus on ecological and relational inclusive development when compared with social development (Gupta \& Vegelin, 2016). Others have focused on specific actions, such as landscape approaches to social and environmental goals (Reed et al., 2016); the use of economic growth and technology as tools for SDG implementation (Salleh, 2016); global governance approaches to integrate the SDGs development agencies with the global financial 
system (Radermacher, 2016); reform towards a common agenda for global institutions through a nexus approach that mirrors the interrelatedness of the SDGs (Boas, Biermann, \& Kanie, 2016b); the effectiveness of multi-stakeholder partnerships in sustainability policy domains such as climate change, health, and biodiversity (Pattberg \& Widerberg, 2016); or the relevance of household-level interventions for food, energy, water, or health (Toole, Klocker, \& Head, 2016). Finally, some studies have questioned the value of related actions: regarding whether an integrated sustainable development multi-sectoral approach could achieve desired outcomes (Nordbeck \& Steurer, 2016) and the unwanted consequences of maladaptive responses to climate change for sustainable development (Magnan et al., 2016). States should be wary of implementing climate policy independently of other sustainable development policies. The SDG and climate agendas have cobenefits but may also lead to unwanted consequences. In some cases, $2{ }^{\circ} \mathrm{C}$ pathways for emission reduction that include, for example, increased use of bioenergy may not be socially optimal since those pathways may negatively affect local food security, some types of livelihoods, water security, biodiversity, and so on (von Stechow et al., 2016). Similarly, adaptation measures such as building sea walls to protect low-lying areas against storm surges caused by rising sea levels may be maladaptive actions that destroy coastal ecosystems, swamps, marshlands, and biodiversity (see also Nunn \& McNamara, this volume). Other papers have addressed ways towards effective climate policymaking and implementation such as my own studies on policy coherence and on accountability in climate policy in Caribbean SIDS (Scobie, 2016, 2017).

This study follows along the lines of earlier environmental governance research, by searching for interlinkages between goals, but is geographically broader since it addresses international to national scales, as well as thematically richer, since it examines the climate change goal in the context of all the SDGs, as well as the implementation pathways chosen by states to achieve these goals. This is arguably the first study that focuses on SIDS and the complex universe of climate and sustainable development policies at the international, regional, and national levels that SIDS' policy implementers manage. It is the first or among the first to use the interlinkages approach to find areas of thematic compatibility between SDG13 on climate change and sustainable development goals more generally. With SIDS as its context, its premise is that the resource constraints of small states make policy integration more of an imperative. The intention of the study is to help remedy climate policy coherence weaknesses by identifying points of compatibility (and dissonance) between two related agendas. It is a good framework to help policymakers and implementers avoid fragmentation in policy development. This may reduce the problem of overlaps and duplication of financial, administrative, and technical resources - particularly acute in development policy in SIDS (Scobie, 2016). 


\section{Methodology}

This chapter highlights the areas where there are thematic interlinkages between the SDGs in general and specifically those related to climate change - a subset of the SDGs. The analysis also highlights what states have considered to be means or pathways to implementation, detailed in the international and national policy documents listed above and illustrated in Figure 1 below. Admittedly, several of the areas that states have listed as "means of implementation" for climate and sustainable development policy can also be found under the list of goals or targets either in the same or other documents. This division between goals and means of implementation used by states is replicated in this paper because it is this framework that national policymakers apply for their own policy formulation.

St. Lucia is used as a case study for the second stage of the research: how far does international policy accord with regional and national policy for SIDS. A content analysis was undertaken of four of the main SIDS' climate change and sustainable development agendas as well as St. Lucia's national policy documents. These documents include the 2014 SAMOA Pathway, the 2013 Kingston Outcome Document (regional outcome document for the UN Samoa summit), the 2014 CARICOM Strategic Plan, the CARICOM Climate Change Implementation Plan, and finally St. Lucia's climate and sustainable development policies. Data on the policies for St. Lucia was obtained from the 2015 St. Lucia Adaptation Policy and its 2015 INDC submission to the UNFCCC. Caribbean climate change implementation plans were taken, for the purposes of this study, from two key documents: the Regional Framework for Achieving Development Resilient to Climate Change (CCCCC, 2009) and its Implementation Plan (CCCCC, 2012).

One of the challenges of governance research in the global south and the Caribbean in particular, is the limited publicly available data on government policy and on project implementation. To address this gap in data, interviews were conducted in 2016 and 2017 with St. Lucia's experts directly involved in climate change and sustainable development policy. These interviews, conducted with ten senior government officials and five leaders of the private sector in St. Lucia, were conducted on the condition of anonymity. The open-ended interviews were helpful for providing guidance on how policies were being conceived and implemented. The small sample size is proportionate to the population (approximately 183,000). Respondents knew each other and reported similar challenges in policy formulation and implementation.

Finally, the research uses the interconnections or interlinkages approach as a pathway to overcome the problematic fragmented or disconnected goals in policy documents. To do this, the framework was used to identify the areas where goals in international, regional, and national policy documents could be integrated (see Figure 1, Table 1, and Table 2). The tables were created using a content analysis of the documents in Figure 1. First, the study found the areas of possible policy synergies between the targets of SDG13 and all the goals and targets of the other 16 
SDGs. The study then proceeded to find the areas of synergy among the policy and implementation plans of the remaining documents in Figure 1. The findings are highlighted in Table 1 and Table 2.

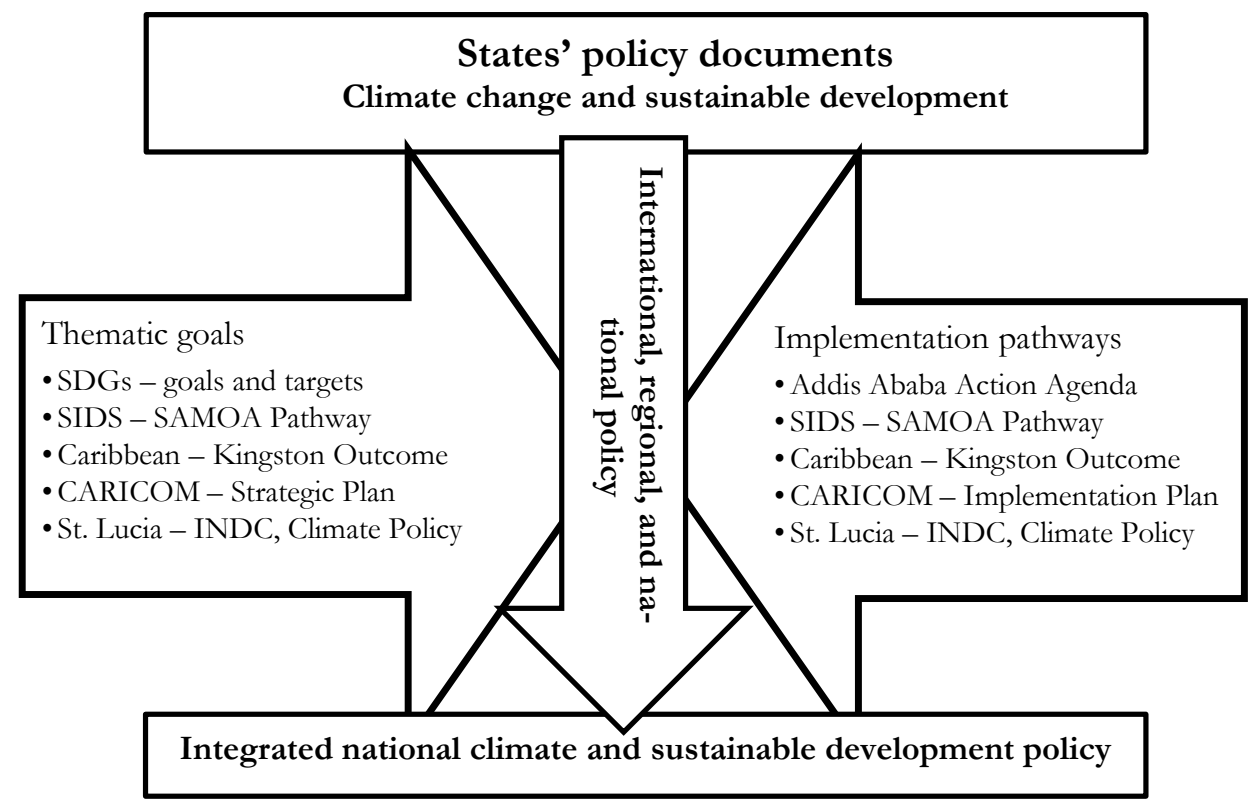

Figure 1: Framework to address the thematic and implementation interlinkages between the agendas of SDG13 on climate change, other UN SDGs, and the development policies of SIDS, CARICOM, and St. Lucia.

\section{SDGs and climate change policy in SIDS}

\subsection{Thematic framework}

The thematic interlinkages framework helps us to answer the following questions: how can climate targets of SDG13 integrate the targets of the remaining SDGs or what are the interconnections between the climate SDG and the others? And, are the same types of interconnections evident at the level of SIDS' policies and at the level of national policy of St. Lucia? This framework - as illustrated below - identifies the several levels of connections between the climate SDG13 and the remaining SDGs and the regional, and national sustainability goals for Caribbean SIDS.. This is useful to facilitate policy integration, especially in the context of limited resources. The framework also helps to illustrate which of the international and SIDS-specific thematic areas are most relevant for Caribbean SIDS and for St. Lucia's policy and where the latter two have other development priorities that are 
not prominent in the international frameworks. Obviously not all international goals have local relevance but where SIDS national goals are not aligned with the international agenda, there may be less attention and funding available from the international institutions for those local goals. Where possible, and for this reason, it is in the interest of SIDS to align their national agendas to global ones.

Table 1: Thematic links between SDG13, the other SDGs, and regional and national policy

\begin{tabular}{|c|c|c|c|c|}
\hline International & \multicolumn{3}{|c|}{ Regional } & National \\
\hline $\begin{array}{l}\text { SDGs related to } \\
\text { climate change }\end{array}$ & $\begin{array}{c}\text { CARICOM } \\
\text { Strategic Plan }\end{array}$ & $\begin{array}{l}\text { St. Lucia Cli- } \\
\text { mate Policy }\end{array}$ & $\begin{array}{l}\text { Kingston Out- } \\
\text { come Docu- } \\
\text { ment }\end{array}$ & $\begin{array}{l}\text { SAMOA Path- } \\
\text { way }\end{array}$ \\
\hline $\begin{array}{l}\text { 1. Poverty Allevi- } \\
\text { ation }\end{array}$ & $\begin{array}{c}\text { Poverty reduc- } \\
\text { tion }\end{array}$ & $\begin{array}{l}\text { Climate proofing } \\
\text { to reduce vulner- } \\
\text { ability - driver of } \\
\text { poverty }\end{array}$ & $\begin{array}{c}\text { Poverty allevia- } \\
\text { tion }\end{array}$ & $\begin{array}{l}\text { Disaster risk } \\
\text { reduction }\end{array}$ \\
\hline $\begin{array}{l}\text { 2. Food Produc- } \\
\text { tivity }\end{array}$ & $* *$ & $\begin{array}{c}\text { Agriculture/Food } \\
\text { Security }\end{array}$ & $\begin{array}{l}\text { Revitalise the } \\
\text { agricultural sector } \\
\text { Food and nutri- } \\
\text { tion security }\end{array}$ & $\begin{array}{l}\text { Food Security } \\
\text { and Nutrition }\end{array}$ \\
\hline 3. Health & $\begin{array}{c}\text { Universal access } \\
\text { to health services; } \\
\text { Reduce mortality } \\
\text { to NCDs and } \\
\text { HIV }\end{array}$ & $\begin{array}{l}\text { Public health } \\
\text { impacts of cli- } \\
\text { mate change }\end{array}$ & $* *$ & $\begin{array}{c}\text { Health and } \\
\text { NCDs }\end{array}$ \\
\hline $\begin{array}{l}\text { 4. Education for } \\
\text { Sustainable } \\
\text { Development }\end{array}$ & $\begin{array}{l}\text { Innovation and } \\
\text { entrepreneurship }\end{array}$ & $\begin{array}{l}\text { Adaptation } \\
\text { awareness and } \\
\text { resilience build- } \\
\text { ing for public and } \\
\text { for private sector }\end{array}$ & $* *$ & $* *$ \\
\hline $\begin{array}{l}\text { 5. Gender } \\
\text { Equality }\end{array}$ & $\begin{array}{l}\text { Mainstream } \\
\text { inclusiveness }\end{array}$ & $\begin{array}{l}\text { Gender main- } \\
\text { streaming in } \\
\text { development } \\
\text { policy }\end{array}$ & $\begin{array}{l}\text { Gender equality } \\
\text { in sustainable } \\
\text { development } \\
\text { programmes }\end{array}$ & $\begin{array}{c}\text { Gender equality, } \\
\text { women's em- } \\
\text { powerment }\end{array}$ \\
\hline $\begin{array}{l}\text { 6. Water Access, } \\
\text { Management }\end{array}$ & $* *$ & $\begin{array}{l}\text { Water conserva- } \\
\text { tion and man- } \\
\text { agement- distri- } \\
\text { bution and effi- } \\
\text { ciency }\end{array}$ & $\begin{array}{c}\text { Freshwater } \\
\text { waste manage- } \\
\text { ment }\end{array}$ & $\begin{array}{l}\text { Water and sanita- } \\
\text { tion; Manage- } \\
\text { ment of chemi- } \\
\text { cals and waste, } \\
\text { including haz- } \\
\text { ardous waste }\end{array}$ \\
\hline
\end{tabular}




\begin{tabular}{|c|c|c|c|c|}
\hline International & \multicolumn{3}{|c|}{ Regional } & National \\
\hline 7. Energy & $\begin{array}{c}\text { Renewable Ener- } \\
\text { gy }\end{array}$ & $\begin{array}{c}\text { Energy efficiency } \\
\text { Renewable Ener- } \\
\text { gy Target (35\%) } \\
\text { by } 2025 \text { and } 50 \% \\
\text { by } 2030 \text { - geo- } \\
\text { thermal, wind, } \\
\text { and solar energy } \\
\text { sources. }\end{array}$ & $\begin{array}{c}\text { Energy re- } \\
\text { sources// securi- } \\
\text { ty //Suitable and } \\
\text { sustainable re- } \\
\text { newable energy } \\
\text { technologies// } \\
\text { Equitable and } \\
\text { universal energy } \\
\text { access }\end{array}$ & $\begin{array}{c}\text { Sustainable } \\
\text { energy }\end{array}$ \\
\hline $\begin{array}{l}\text { 8. Inclusive } \\
\text { Economic } \\
\text { Growth }\end{array}$ & $\begin{array}{l}\text { Sustainable } \\
\text { economic growth } \\
\text { Innovation and } \\
\text { entrepreneurship }\end{array}$ & $\begin{array}{l}\text { Link between } \\
\text { economic } \\
\text { growth/resilience } \\
\text { and economic } \\
\text { impacts of ex- } \\
\text { treme events }\end{array}$ & Tourism & $\begin{array}{l}\text { Sustained and } \\
\text { sustainable, } \\
\text { inclusive and } \\
\text { equitable eco- } \\
\text { nomic growth } \\
\text { with decent work } \\
\text { for all }\end{array}$ \\
\hline $\begin{array}{l}\text { 9. Infrastructure, } \\
\text { Industrialisation, } \\
\text { Innovation }\end{array}$ & $\begin{array}{c}\text { Technology as a } \\
\text { tool to build } \\
\text { regional econom- } \\
\text { ic competitive- } \\
\text { ness }\end{array}$ & $\begin{array}{c}\text { Climate } \\
\text { proof/risk as- } \\
\text { sessment for } \\
\text { critical infrastruc- } \\
\text { ture }\end{array}$ & & $\begin{array}{l}\text { Sustainable } \\
\text { transport }\end{array}$ \\
\hline $\begin{array}{c}* * 10 . \text { Equality } \\
\text { within and } \\
\text { among Countries }\end{array}$ & $* *$ & $* *$ & $* *$ & $* *$ \\
\hline $\begin{array}{c}* * \text { 11. Safe, Resil- } \\
\text { ient, Sustainable } \\
\text { Cities }\end{array}$ & $* *$ & $* *$ & $* *$ & $* *$ \\
\hline $\begin{array}{l}\text { 12. Sustainable } \\
\text { Consumption } \\
\text { and Production }\end{array}$ & $\begin{array}{l}\text { Tourism and } \\
\text { agriculture }\end{array}$ & $\begin{array}{l}\text { Vulnerability of } \\
\text { tourism sector to } \\
\text { climate impacts }\end{array}$ & Tourism & $\begin{array}{c}\text { Sustainable } \\
\text { consumption and } \\
\text { production }\end{array}$ \\
\hline $\begin{array}{l}\text { 14. Oceans, Seas, } \\
\text { Marine Resources }\end{array}$ & $* *$ & $\begin{array}{c}\text { Adaptation to } \\
\text { ocean and coastal } \\
\text { changes caused } \\
\text { by climate change }\end{array}$ & $\begin{array}{c}\text { Coastal and } \\
\text { marine govern- } \\
\text { ance// Tourism }\end{array}$ & Oceans and seas \\
\hline
\end{tabular}




\begin{tabular}{|c|c|c|c|c|}
\hline International & \multicolumn{3}{|c|}{ Regional } & National \\
\hline $\begin{array}{l}\text { 15. Terrestrial } \\
\text { Ecosystems, } \\
\text { Forests, Deserti- } \\
\text { fication, Land } \\
\text { Degradation, } \\
\text { Habitat, and } \\
\text { Biodiversity Loss }\end{array}$ & ** & $\begin{array}{c}\text { Land use plan- } \\
\text { ning and risk } \\
\text { assessments to } \\
\text { reduce vulnera- } \\
\text { bility to extreme } \\
\text { events } \\
\text { Biodiversity } \\
\text { conservation } \\
\text { Forest manage- } \\
\text { ment }\end{array}$ & $\begin{array}{l}\text { Land manage- } \\
\text { ment// Biodiver- } \\
\text { sity }\end{array}$ & $\begin{array}{l}\text { Biodiversity// } \\
\text { Desertification, } \\
\text { land degradation } \\
\text { and drought// } \\
\text { Invasive alien } \\
\text { species }\end{array}$ \\
\hline $\begin{array}{c}* * 16 . \text { Peaceful } \\
\text { and Inclusive } \\
\text { Societies }\end{array}$ & $\begin{array}{l}* * \text { Address trans- } \\
\text { national crime } \\
\text { Regional security }\end{array}$ & ** & $* *$ & $* *$ \\
\hline $\begin{array}{l}\text { 17. Means of } \\
\text { Implementation, } \\
\text { Partnerships for } \\
\text { Sustainable } \\
\text { Development }\end{array}$ & ** & $\begin{array}{l}\text { International } \\
\text { financing } \\
\text { Partnerships with } \\
\text { the private sector } \\
\text { Sustainable } \\
\text { Financing for } \\
\text { climate policy } \\
\text { Human, institu- } \\
\text { tional and tech- } \\
\text { nical capacity } \\
\text { building } \\
\text { Data building and } \\
\text { management } \\
\text { Technology } \\
\text { transfer }\end{array}$ & $\begin{array}{c}\text { Data collection } \\
\text { and management }\end{array}$ & $\begin{array}{l}\text { Means of imple- } \\
\text { mentation in- } \\
\text { cluding partner- } \\
\text { ships // } \\
\text { Monitoring and } \\
\text { accountability }\end{array}$ \\
\hline ** & $\begin{array}{c}\text { Resilience to } \\
\text { natural disasters }\end{array}$ & Climate proofing & Natural disasters & $\begin{array}{l}\text { Disaster risk } \\
\text { reduction }\end{array}$ \\
\hline ** & $* *$ & ** & ** & $\begin{array}{c}* * \text { Social devel- } \\
\text { opment }\end{array}$ \\
\hline$* *$ & $\begin{array}{l}\text { Improve efficien- } \\
\text { cy of community } \\
\text { organizations }\end{array}$ & ** & $* *$ & ** \\
\hline
\end{tabular}

Notes: **References to similar policies and goals are absent.

Table 1 illustrates the thematic interconnections between SDG13 and the remaining climate and sustainable development policy documents that form the basis of SIDS' policy: the SAMOA Pathway, the 2013 Kingston Outcome Document, 
and the CARICOM Strategic Plan. Highlighted with the two asterisks $(* *)$ are the areas where references to similar policies are missing when comparing international, regional, and national goals and objectives.

All SDGs and 55 of their targets are related to SDG13 and its targets. For example, the climate goal is linked to SDG1 on poverty alleviation, specifically targets 1.1, 1.2, 1.3, 1.5, and 2. Although the study produced a detailed mapping of the SDGs' interlinkages with SDG13, this was not reproduced here in the interest of space. While the SDGs divide objectives into "goals" and "targets", the CARICOM Strategic Plan refers to multiple "goals" and "objectives" for each of its strategic priorities. At the national level, St. Lucia's adaptation and mitigation targets are linked to at least ten of the SDGs including improved quality of life and poverty alleviation - two areas most affected by hurricanes. St. Lucia's INDC highlights six policy goals or areas, all linked to sustainable development: energy demand and electricity generation; transportation; agriculture and fisheries; waste; land use/land use change and forestry; industrial processes; and a wide general category (including governance, education, and national policy development).

St. Lucia's INDC recognises the close connection between climate change mitigation and sustainable development: "the best way to address climate change impacts is by integrating adaptation measures into sustainable development strategies", and "adaptation [disaster risk preparedness] measures are conducive to sustainable development, even without the connection with climate change" (Government of St. Lucia, 2015a, p. 5). The majority of SIDS' development goals are related to the international SDGs and climate change agendas, with a few exceptions. Notably, SIDS did not directly address SDG10 (equality between countries) or SDG11 (cities). SIDS thematic goals are strongly weighted towards attention given to the impacts of natural hazards, waste management, and organisational and institutional efficiency. SIDS view sustainable development as directly related to reducing and managing environmental vulnerability. Natural hazards affect the economy, the environment, and the society. The high levels of poverty mean that limited resources are available to address basic needs. SIDS' economies take longer to recover since the infrastructure and sectors upon which SIDS' narrow export bases depend are usually destroyed. Institutional change and comprehensive infrastructure and waste and water management in these contexts require sustainable financing but most financed projects are pilot projects that operate on time scales that are short compared to what these islands need to make the projects sustainable. The war on crime, which may be linked to SDG16 (peaceful societies), has become one of the Caribbean SIDS' development hurdles. Climate change impacts contribute to unemployment, poverty, and weakened social services, which leads to social exclusion, youth unemployment, and higher incidence of crime. Caribbean SIDS are particularly vulnerable to crime since they are geographically located between the southern suppliers and northern consumers of illicit drugs and are affected by the illicit narcotics trade of transnational crime (UNODC, 2012). 


\subsection{Implementation policies}

The previous section illustrated the thematic interlinkages between the sustainable development and climate change agendas at international to national levels. This section does the same for the implementation agendas as defined by states. Although it is difficult to draw a clear line between key sustainable development and climate change goals and their implementation pathways, states have often separated goals from implementation pathways, either as sections of a single document, as in the SAMOA Pathway, or in two separate international processes and outcome documents, as with the SDGs and the Addis Ababa Action Agenda (AAAA). The linkages are illustrated in Table 2 . Highlighted with the two asterisks $\left(^{* *}\right)$ are the areas where references to similar policies are missing when comparing international, regional, and national agendas.

Table 2: Links between means of implementation of climate and sustainable development policy at international, regional, and national levels

\begin{tabular}{|c|c|c|c|c|}
\hline International & \multicolumn{3}{|c|}{ Regional } & National \\
\hline $\begin{array}{l}\text { Addis Ababa } \\
\text { Financing } \\
\text { Action Agen- } \\
\text { da }\end{array}$ & $\begin{array}{l}\text { SAMOA means } \\
\text { of implementa- } \\
\text { tion }\end{array}$ & $\begin{array}{l}\text { Kingston Out- } \\
\text { come Docu- } \\
\text { ment }\end{array}$ & $\begin{array}{l}\text { CCCCC Imple- } \\
\text { mentation Plan } \\
\text { for Achieving } \\
\text { Development } \\
\text { Resilient to Cli- } \\
\text { mate Change }\end{array}$ & $\begin{array}{l}\text { St. Lucia Cli- } \\
\text { mate Policy }\end{array}$ \\
\hline $\begin{array}{l}\text { Domestic } \\
\text { public re- } \\
\text { sources }\end{array}$ & Partnerships & $* *$ & $* *$ & $\begin{array}{l}\text { Mobilisation of } \\
\text { community and } \\
\text { private sector } \\
\text { finance }\end{array}$ \\
\hline $\begin{array}{l}\text { Domestic and } \\
\text { international } \\
\text { private busi- } \\
\text { ness and } \\
\text { finance }\end{array}$ & $\begin{array}{l}\text { Partnerships, } \\
\text { financing }\end{array}$ & $\begin{array}{c}\text { Investments for } \\
\text { technology devel- } \\
\text { opment }\end{array}$ & $\begin{array}{c}\text { Investment for } \\
\text { achieving objec- } \\
\text { tives; } \\
\text { Gain international } \\
\text { funding }\end{array}$ & $\begin{array}{l}\text { Facilitate private } \\
\text { investment into } \\
\text { climate proofing }\end{array}$ \\
\hline $\begin{array}{l}\text { International } \\
\text { development } \\
\text { cooperation }\end{array}$ & Financing & $\begin{array}{l}\text { Financing for } \\
\text { development }\end{array}$ & $\begin{array}{l}\text { Systems for coop- } \\
\text { eration among } \\
\text { regional agencies }\end{array}$ & $\begin{array}{c}\text { Sustainable } \\
\text { financial flows } \\
\text { for climate } \\
\text { change }\end{array}$ \\
\hline $\begin{array}{l}\text { International } \\
\text { trade as an } \\
\text { engine for } \\
\text { development }\end{array}$ & $\begin{array}{c}\text { Trade, partner- } \\
\text { ships }\end{array}$ & $* *$ & $* *$ & $* *$ \\
\hline $\begin{array}{l}\text { Debt and debt } \\
\text { sustainability }\end{array}$ & Financing, trade & $\begin{array}{l}\text { Debt manage- } \\
\text { ment and flexible } \\
\text { financing }\end{array}$ & ** & $* *$ \\
\hline
\end{tabular}




\begin{tabular}{c|c|c|c|c}
\hline International & \multicolumn{3}{|c|}{ Regional } & National \\
\hline $\begin{array}{c}\text { Addressing } \\
\text { systemic issues }\end{array}$ & $\begin{array}{c}\text { Partnerships; } \\
\text { Technology// } \\
\text { capacity building }\end{array}$ & $* *$ & $* *$ & $\begin{array}{c}\text { Create the ena- } \\
\text { bling environ- } \\
\text { ment - legisla- } \\
\text { tion, fiscal, } \\
\text { governance }\end{array}$ \\
\hline $\begin{array}{c}\text { Science, tech- } \\
\text { nology, inno- } \\
\text { vation, and } \\
\text { capacity build- } \\
\text { ing }\end{array}$ & $\begin{array}{c}\text { Data and statis- } \\
\text { tics; } \\
\text { Institutional } \\
\text { support to SIDS }\end{array}$ & $\begin{array}{c}\text { Data collection } \\
\text { and management }\end{array}$ & $* *$ & $\begin{array}{c}\text { Technology } \\
\text { transfer and } \\
\text { capacitybuilding }\end{array}$ \\
\hline $\begin{array}{c}\text { Data, monitor- } \\
\text { ing and fol- } \\
\text { low-up }\end{array}$ & $\begin{array}{c}\text { Institutional } \\
\text { support to SIDS }\end{array}$ & $\begin{array}{c}\text { Data collection } \\
\text { and management } \\
* *\end{array}$ & $\begin{array}{c}\text { Reclassification } \\
\text { of SIDS for } \\
\text { treater access to } \\
\text { concessionary } \\
\text { financing } \\
\text { tion }\end{array}$ & $\begin{array}{c}\text { Dor moni- } \\
\text { Datal building }\end{array}$ \\
\hline and management \\
\hline
\end{tabular}

Note: $* *$ References to similar policies and goals are absent.

The AAAA was the outcome document of the 2015 Addis Ababa Third International Conference on Financing for Development. It is a global framework for financing sustainable development that aligns financing flows and policies with economic, social, and environmental priorities. At the level of SIDS, the 2014 SAMOA Pathway outlined SIDS' action agenda for sustainable development just one year earlier and some of these pathways were also reflected in the AAAA. SIDS focused on seven areas: partnerships, financing, trade, capacity building, technology, data and statistics, and institutional strengthening. The 2013 Kingston Outcome Document includes a roadmap entitled "Strengthening the Implementation Framework", with 21 action areas related to sustainable development and climate change that overlapped in some areas with the SAMOA Pathway. Interestingly, Caribbean states also include some different implementation priorities: debt management, expansion of concessionary financing for SIDS, and the importance of financial agencies' reclassifying Caribbean SIDS (many now classed as high- or medium-income countries) to low-income countries. Caribbean SIDS argue that existing classifications ignore their levels of income inequality, economic and climatic precariousness and vulnerability and bars their countries' access to development financing.

The 2013 Kingston Outcome Document identified five implementation pathways towards sustainable development - all are linked to the region's climate change agenda. St. Lucia's national policy documents did not distinguish between 
goals and actions. The Adaptation Policy outlines three adaptation pathways that it calls "measures" or future outputs: facilitation, implementation, and financing.

Understandably SIDS' implementation pathways focus on financing for climate policy and sustainable development policy. Sustainable financing for environmental projects in SIDS has lacked continuity for several reasons. A policy may be terminated when a new political party is elected and discontinues a programme or when political will wanes (Scobie, 2016). Many SIDS continue to depend upon external project funding often available only through pilot or time-limited projects. Development programmes are often shaped by the requirements of external funding agencies and interventions lapse when the funding is exhausted. St. Lucia notes this funding trap: "There is a gradual recognition that the current situation of financial support for climate change action in Saint Lucia - characterized by a large number of international funds with complex administrative processes, minimal transparency or accountability, and conflicting mandates that do not always address or respond to Saint Lucia's concerns or priorities - is untenable" (Government of St. Lucia, 2015a, p. 18). To remedy this problem, the Adaptation Policy focused on local and sustainable funding by involving the private sector in adaptation financing. All policy documents in Table 2 address the need to mobilise domestic resources. SIDS also continue to emphasise international support (partnerships, private investment, funding from developed states) as a sine qua non for policy implementation. In the SAMOA Pathway this is framed in the language of "partnerships" between the state and other (wealthier) actors. The Kingston Outcome Document suggests that private funding is helpful for "encouraging investment" in technology development.

Table 2 also highlights areas of notable disconnect between international and SIDS agendas. SIDS' access to concessionary financing is contentious and while addressed in their policy documents, this issue is not reflected in the AAAA. Although international goals and action agendas do not have to incorporate all priorities of particular states or groups of states, it is remarkable that the international or global agenda is silent on an issue that Caribbean SIDS consider central to achieving their climate and sustainable development objectives.

\subsection{Discussion on interlinkages}

The overview of climate and sustainable development goals and targets - from international to national - shows many areas of convergence, but also some areas of divergence in the case of SIDS. The interlinkages approach is helpful for uncovering the thematic links between international, regional, and national climate and sustainable development goals. The climate SDG13 is linked to all of the remaining 16 SDGs and to 55 of the 169 SDG targets. Several (at least 18) SIDS development goals are also linked to SDG13. At the Caribbean level, there are links between at least 11 of the regional development priorities and SDG13 (6 of the Kingston Outcome Document and 5 of the Strategic Plan goals) (CCCCC, 2009, 
2012). This framework or interlinkages approach also reveals areas of divergence where international goals have no related area of focus for SIDS, such as DRR and crime.

There are many commonalities between what states have identified as implementation agendas. At least eight action points for the AAAA are linked to goals in the SAMOA Pathway. Perhaps the most striking point of divergence is the issue of access to finance. Caribbean SIDS share a "twin resource mobilization problem": limited possibilities to mobilise both domestic and external funding (Bourne, Alexander, Conrad, \& Jhinkoo, 2015) and Caribbean SIDS struggle to attract regular flows of foreign direct investment. St. Lucia's Adaptation Policy states that its execution is in part predicated on external financing: "the success of the CCAP will be dependent on national budgetary contributions, as well as support from regional agencies and programs and international donor and financial institutions" (Government of St. Lucia, 2015a, p. 17). Most Caribbean SIDS are now classed as upper-middle-income countries although they continue to struggle with the vulnerabilities and challenges that all SIDS have to achieve social and economic development and to adapt to climate change. Their debt service obligations reduce fiscal capacity for capital investment and economic growth. The Kingston Outcome Document prioritises the reclassification of SIDS to low-income states so that they may have access to concessionary financing. The World Bank's allocation to Caribbean States is small and has been decreasing. Overseas development assistance has also decreased as aid has shifted to low-income and post-conflict nations (Bourne et al., 2015). Within this context, it is understandable that Caribbean SIDS would include their reclassification to low-income countries, for the purpose of concessionary financing, as a priority and it is significant that the issue is not reflected in the international action agendas.

Another notable finding from the table is the way SIDS have framed some of their traditional challenges to suit new international agendas. Policymakers interviewed for this paper lamented but confirmed that SIDS have had to reframe their development priorities in the language of, or to concord with, the international goals, in order to tap into the international funding streams associated with these international goals. For example, SIDS' tourism and agricultural sectors have always suffered from natural hazards such as flooding or storms that predate climate change. For these states, DRR and resilience have greater national priority. However, framing DRR as climate resilience concords better with the international climate adaptation agenda and allows SIDS to tap into climate funding. Similarly, St. Lucia's climate policy includes mitigation although the island's carbon footprint is minimal. Specifically, St. Lucia's economy will benefit from reduced fuel import costs and lower economic exposure to fluctuations in global fuel prices. This economic policy is framed, also for the purposes of obtaining international funding and technical support, as a mitigation goal related to clean energy production and an SDG related to energy security. 
SIDS do not mention equality between countries (SDG10) among their sustainable development targets. Their references to comparisons between countries refer to their special needs for financing and capacity building for sustainable development. In addition, SIDS have not addressed safe, resilient, and sustainable cities (SDG11) and this may be because of scalar realities: few SIDS have the sustainability challenges of larger urban populations (Mycoo \& Donovan, 2017). Urbanisation for SIDS can relate to a small town connected by villages along the coast, or on a single island state and SIDS need not separate urbanisation as a separate sustainable development challenge (UN-HABITAT, 2015). Singapore's entire population (5.1 million) and most of Puerto Rico's ( 3.7 million out of 3.74 million), for instance, are urban. Of the 49 remaining SIDS, few have urban populations over 1 million people: Dominican Republic ( 7.0 million), Cuba (8.5 million), Bahrain (1.2 million), Haiti (5.4 million), and Jamaica (1.4 million). In each case, all major cities within the state are included in this calculation of urban populations (UN-HABITAT, 2015). Also on the point of divergence, SIDS generally gave less priority to SDG16 (peaceful and inclusive societies), although, as discussed above, crime and regional security were mentioned in the CARICOM Strategic Plan (UNODC, 2012).

\section{Conclusion}

This study points to the links between several areas of international and national climate and sustainable development policy, goals, and targets. The implementation strategies are listed in policy documents as separate goals and action items that are then the responsibility of separate international and national agencies responsible for implementation. The UN's 34 funds, programmes, and specialised agencies reflect these thematic goals or targets and institutionally entrench them through their streams of development cooperation to SIDS. In practice, SIDS' national agencies, structured around the goals and targets of the SDGs, compete for an always shrinking pot of development funds. Separate implementation of goals by agencies when, as this study exemplifies, the goals are interlinked, leads to a duplication of efforts and the inefficient use of scarce resources that SIDS can ill afford (Helgason, 2016; Scobie, 2016).

Alternatively, and using this framework, any action, for example on SDG1 (poverty alleviation), should involve departments in government working on poverty alleviation (Kingston Outcome Document goal), poverty reduction (CARICOM Strategic Plan), DRR (SAMOA Pathway), and climate change (SDG13). Projects should be co-created and jointly implemented by public and private stakeholders in the related areas (Scobie, 2016) - always linking these goals and the many sub-goals and targets under each heading in the framework table (detailed in the documents mentioned above). Similarly, departments working on SDG8 (inclusive economic growth) should work with all departments and stake- 
holders working on climate change, but also with those working to reduce the impacts of extreme events (St. Lucia Climate Policy goal) on innovation and entrepreneurship and sustainable economic growth (CARICOM goal), tourism (Kingston Outcome Document), and decent work (SAMOA Pathway).

There is also scope, using the table, to link some of these policy and implementation areas to departments and stakeholders working on other SDGs related to SDG8 and climate change. There are linkages between the inclusive economic growth goal (SDG8) and equitable and universal energy access (Kingston Outcome Document goal), and departments working on energy can develop joint projects with those on inclusive economic growth. In the cases where the national or regional goal is not also a goal at the international level - like the CARICOM goal on the need to address crime and regional security - to obtain international funding and technical assistance, departments working on that goal, would then have to find ways to link that goal with other related SDGs. Since SDG16 (on peaceful and inclusive societies), to which the CARICOM goal on crime may be linked, is also linked to climate change, CARICOM states can then leverage the importance of climate policy to help to avoid some of the societal weaknesses exacerbated by climate impacts - such as poverty and poor social services - to SDG16 to leverage funding associated with climate change and SDG16 for the CARICOM goal on crime.

More recently, St. Lucia created an institutional structure to facilitate collaboration on climate change and the framework of this paper can assist in establishing areas of joint interest and action among agencies. Saint Lucia's National Adaptation Plan (NAP) 2018-2028 (published after the study was completed) signalled the creation of a National Climate Change Committee - comprised of representatives from ministries of sustainable development, agriculture, physical planning, health, education, tourism, finance, infrastructure, national insurance, national conservation, electricity, solid waste management, air and sea ports, water and sewage, and the bankers association - to improve institutional coordination between the government agencies that manage climate related goals. Interview partners noted that the success of such cross-departmental efforts depends on the willingness of departments to share information and resources and to allow other agencies to lead on international financing projects. According to Caribbean policymakers, although in some government departments such a collaborative culture exists, in many others it is lacking unless specific funding and performance targets are introduced (Scobie, 2016).

This chapter illustrates where there are linkages between climate goals and the SDGs at international to national levels with St. Lucia as an example, while showing areas of convergence and divergence and the challenging complexity and multiplicity of goals. In doing so it responds to calls in the literature to identify nexus points in development approaches (Boas et al., 2016a). By identifying the areas of connection between the SDGs and climate change, the study offers policymakers a 
framework to approach international, regional, and national climate change and development policy more holistically in policy formulation.

International funding and development assistance are managed through separate UN agencies that are structured along the lines of the SDGs. SIDS policymakers struggle to implement multiple targets and goals that they have committed to at international and regional forums. They have limited resources and the handicap of economic and environmental vulnerability that reduce their control over future income and future expenditure. The national ministries or agencies of government often replicate the thematic divisions of the SDGs and independently implement policies that have the potential to achieve several SDGs. It is up to policy implementers to recognise the interrelationships if they are to use resources more efficiently and St. Lucia's National Climate Change Committee is a promising example of an institutional structure that may facilitate this. For SIDS policymakers and their development partners and committees like the St. Lucia Climate Change Committee, the frameworks presented in the tables of this chapter are tools for policymaking and implementation since they immediately signal the otherwise separate development goals and potentially can more readily help identify how several sustainable development and climate goals can be achieved though one policy intervention.

\section{Bibliography}

Boas, I., Biermann, F., \& Kanie, N. (2016b). Cross-sectoral strategies in global sustainability governance: Towards a nexus approach. International Environmental Agreements-Politics Law and Economics, 16(3), 449-464.

Bourne, C., Alexander, M., Conrad, D., \& Jhinkoo, J. (2015). Financing for development challenges in Caribbean SIDS: A case for review of eligibility criteria for access to concessional financing. Retrieved from Port of Spain, Trinidad and Tobago: http://www.undp.org/content/dam/rblac/docs/Research\%20and $\% 20$ Publications/Poverty $\% 20$ Reduction/UNDP_RBLAC_Financing_for_ Development_ReportCaribbean.pdf.

CARICOM. (2013). Kingston outcome of the Caribbean regional preparatory meeting for the Third International Conference on Small Island Developing States (SIDS). Georgetown Guyana: Caribbean Community.

CARICOM. (2014). Strategic plan for the Caribbean Community 2015-2019: Repositioning CARICOM. Retrieved from Turkeyen, Guyana: https://caricom.org/ documents/11265-executive_plan_vol_1_-_final.pdf.

CCCCC. (2009). Climate change and the Caribbean: A regional framework for achieving development resilient to climate change (2009-2015). Belize: Caribbean Community Climate Change Centre.

CCCCC. (2012). Delivering transformational change 2011-21. Implementing the CARICOM "Regional Framework for Achieving Development Resilient to Climate Change" 
Belize: Caribbean Community Climate Change Centre and the Climate and Development Knowledge Network.

Ferguson, J. (1998). A case of bananas. Geographical Journal 70(1), 49-52.

Government of St. Lucia. (2015a). The Saint Lucia climate change adaptation policy. Castries, St. Lucia: Government of St. Lucia.

Government of St. Lucia. (2015b). Saint Lucia, intended nationally determined contribution under the United Nations Framework Convention on Climate Change. Castries, St. Lucia: Government of St. Lucia.

Griggs, D., Smith, M. S., Rockström, J., Öhman, M. C., Gaffney, O., Glaser, G., . . - Shyamsundar, P. (2014). An integrated framework for sustainable development goals. Ecology \& Society, 19(4), 1-24.

Gupta, J., \& Vegelin, C. (2016). Sustainable development goals and inclusive development. International Environmental Agreements-Politics Law and Economics, 16(3), 433-448.

Hall, R. P., Ranganathan, S., \& Raj, G. C., K. (2017). A general micro-level modeling approach to analyzing interconnected SDGs: Achieving SDG 6 and more through multiple-use water services (MUS). Sustainability, 9(2).

Helgason, K. S. (2016). The 2030 agenda for sustainable development: Recharging multilateral cooperation for the post-2015 era. Global Policy, 7(3), 431-440.

Hutton, G., \& Chase, C. (2016). The knowledge base for achieving the sustainable development goal targets on water supply, sanitation and hygiene. International Journal of Environmental Research and Public Health, 13(6), 536.

Koehler, G. (2016). Assessing the SDGs from the standpoint of eco-social policy: Using the SDGs subversively. Journal of International and Comparative Social Policy, 32(2), 149.

Lamb, W. F. (2016). Which countries avoid carbon-intensive development? Journal of Cleaner Production, 131, 523-533.

Le Blanc, D. (2015). Towards integration at last? The sustainable development goals as a network of targets. Sustainable Development, 23(3), 176-187.

Magnan, A. K., Schipper, E. L. F., Burkett, M., Bharwani, S., Burton, I., Eriksen, S., . . Z Ziervogel, G. (2016). Addressing the risk of maladaptation to climate change. WIREs Climate Change, 7(5), 646-665.

Moberg, M. (2005). Fair trade and Eastern Caribbean banana farmers: Rhetoric and reality in the anti-globalization movement. Human Organization, 64(1), 4 15.

Mycoo, M., \& Donovan, M. G. (2017). A blue urban agenda: Adapting to climate change in the coastal cities of Caribbean and Pacific Small Island Developing States. InterAmerican Development Bank.

Nelson, D. R., Lemos, M. C., Eakin, H., \& Lo, Y. J. (2016). The limits of poverty reduction in support of climate change adaptation. Environmental Research Letters, 11(9), 7. 
Nilsson, M., Griggs, D., Visbeck, M., Ringler, C., \& McCollum, D. (2017). A Guide to SDG Interactions: from Science to Implementation. Paris: International Council for Science.

Nilsson, M., Lucas, P., \& Yoshida, T. (2013). Towards an integrated framework for SDGs: Ultimate and enabling goals for the case of energy. Sustainability, 5(10), 4124-4151.

Nordbeck, R., \& Steurer, R. (2016). Multi-sectoral strategies as dead ends of policy integration: Lessons to be learned from sustainable development. Environment and Planning C-Government and Policy, 34(4), 737-755.

Pattberg, P., \& Widerberg, O. (2016). Transnational multistakeholder partnerships for sustainable development: Conditions for success. Ambio, 45(1), 42-51.

Radermacher, F. J. (2016). Twelve Action Lines for a Better World: Finally Realizing the Four Major Responsibilities. Cadmus, 2(6, Part 1), 60.

Reed, J., Van Vianen, J., Deakin, E. L., Barlow, J., \& Sunderland, T. (2016). Integrated landscape approaches to managing social and environmental issues in the tropics: Learning from the past to guide the future. Global Change Biology, 22(7), 2540-2554.

Ribas, A., Lucena, A. F. P., \& Schaeffer, R. (2017). Bridging the energy divide and securing higher collective well-being in a climate-constrained world. Energy Policy, 108(Supplement C), 435-450.

Ringler, C., Willenbockel, D., Perez, N., Rosegrant, M., Zhu, T., \& Matthews, N. (2016). Global linkages among energy, food and water: An economic assessment. Journal of Environmental Studies \& Sciences, 6(1), 161.

Roberts, E., Andrei, S., Huq, S., \& Flint, L. (2015). Resilience synergies in the post2015 development agenda. Nature Climate Change, 5(12), 1024-1025.

Ruiz-Mallén, I., Fernández-Llamazares, Á., \& Reyes-García, V. (2017). Unravelling local adaptive capacity to climate change in the Bolivian Amazon: The interlinkages between assets, conservation and markets. Climatic Change, 140(2), 227-242.

Salleh, A. (2016). Climate, water, and livelihood skills: A post-eevelopment reading of the SDGs. Globalizations, 13(6), 952-959.

Schandl, H., Hatfield-Dodds, S., Wiedmann, T., Geschke, A., Cai, Y., West, J., . . . Owen, A. (2016). Decoupling global environmental pressure and economic growth: Scenarios for energy use, materials use and carbon emissions. Journal of Cleaner Production, 132, 45-56.

Scobie, M. (2016). Policy coherence in climate governance in Caribbean Small Island Developing States. Environmental Science \& Policy, 58, 16-28.

Scobie, M. (2017). Accountability in climate change governance and Caribbean SIDS. Environment, Development and Sustainability, 20(2), 769-787.

Scobie, M. (2019). Chapter 6: Renewable energy and energy security, and Caribbean SIDS. In Global environmental governance and small states: Architectures and agency in the Caribbean (pp. 118-146). UK: Edward Elgar Publishing. 
Sherman, M., Berrang-Ford, L., Lwasa, S., Ford, J., Namanya, D. B., LlanosCuentas, A., . . . Team, I. R. (2016). Drawing the line between adaptation and development: A systematic literature review of planned adaptation in developing countries. WIREs Climate Change, 7(5), 707-726.

Shingirai, S. M., \& Happy, M. T. (2017). Climate change: A threat towards achieving 'Sustainable Development Goal number two' (end hunger, achieve food security and improved nutrition and promote sustainable agriculture) in South Africa. Jàmbá: Journal of Hazard Risk Studies, 9(1), e1-e6.

Singh, G. G., Cisneros-Montemayor, A. M., Swartz, W., Cheung, W., Guy, J. A., Kenny, T.-A., . . Ota, Y. (2018). A rapid assessment of co-benefits and trade-offs among Sustainable Development Goals. Marine Policy, 93, 223 231.

Subhash Janardhan, B. (2016). Paris Agreement on Climate Change: A booster to enable sustainable global development and beyond. International Journal of Environmental Research and Public Health, 13(11), 1134.

Taylor, M. A., Jones, J. J., \& Stephenson, T. S. (2016). Climate change and the Caribbean: Trends and implications. In E. Thomas-Hope (Ed.), Climate change and food security: Africa and the Caribbean (pp. 31-55). London: Routledge.

Toole, S., Klocker, N., \& Head, L. (2016). Re-thinking climate change adaptation and capacities at the household scale. Climatic Change, 135(2), 203-209.

UN-HABITAT. (2015). Urbanization and climate change in Small Island Developing States. Nairobi, Kenya: United Nations Human Settlements Programme.

UNGA. (2014). SIDS Accelerated Modalities Of Action [S.A.M.O.A.] Pathway. (A/RES/69/15 -). New York: UNGA

UNODC. (2012). Transnational organized crime in Central America and the Caribbean: A threat assessment. Retrieved from Vienna: https://www.unodc.org/ documents/data-and-analysis/Studies/TOC_Central_America_and_the_ Caribbean_english.pdf.

von Stechow, C., Minx, J. C., Riahi, K., Jewell, J., McCollum, D. L., Callaghan, M. W., . . Baiocchi, G. (2016). $2{ }^{\circ} \mathrm{C}$ and SDGs: United they stand, divided they fall? Environmental Research Letters, 11(3).

Wagner, L., Ross, I., Foster, J., \& Hankamer, B. (2016). Trading off global fuel supply, CO2 emissions and sustainable development. Plos One, 11(3), e0149406.

Yillia, P. (2016). Water-Energy-Food nexus: Framing the opportunities, challenges and synergies for implementing the SDGs. Water Energy Food Nexus: Ausarbeitung der Möglichkeiten, Herausforderungen und Synergien bei der Umsetzung der Ziele der nachhaltigen Entwicklung (SDG). 68(3/4), 86.

Zhang, Q., Prouty, C., Zimmerman, J. B., \& Mihelcic, J. R. (2016). Research: More than Target 6.3: A systems approach to rethinking sustainable development goals in a resource-scarce world. Engineering, 2, 481-489. 